\title{
Looming Diasporic in-Betweenness: A Critical Study of Hybridity and Culture in Agha Shahid Ali's Poetic World
}

\author{
Ajay S. Deshmukh \\ Department of English \\ Shri. Muktanand College \\ Gangapur, Aurangabad, Maharashtra, India \\ ajayd802@gmail.com
}

Rajdeep R. Deshmukh

Department of English

Shri. Muktanand College

Gangapur, Aurangabad, Maharashtra, India

\section{Abstract}

Hybridity is an outcome of consistent movement and interaction of two different aspects of human existence. The forces of nature when confluence each other cause hybrid existence bringing the traces of both into it. It may by and large cohabit the space and time, race and culture, philosophy and religion etc. It encompasses the divergent modes of existence, thinking patterns, behavioral norms, socio-cultural ethos, political and administrative ambience. Diasporic Hybridity is pertinent discourse. It is cause of anxiety in the early stage of migrant experience whereas settling base of later stage of existence of diasporic community. Present paper is an attempt to trace the threads of looming diasporic inbetweenness as reflected in the poetry of Agha Shahid Ali. 
Keywords: Diaspora, Hybridity, Culture, Poetry Introduction

Hybridity is an outcome of consistent movement and interaction of two different aspects of human existence. The forces of nature when confluence each other cause hybrid existence bringing the traces of both into it. It may by and large cohabit the space and time, race and culture, philosophy and religion etc. It encompasses the divergent modes of existence, thinking patterns, behavioral norms, socio-cultural ethos, political and administrative ambience. Diasporic Hybridity is pertinent discourse. It is cause of anxiety in the early stage of migrant experience whereas settling base of later stage of existence of diasporic community.

Present paper is an attempt to trace the threads of looming diasporic in-betweenness as reflected in the poetry of Agha Shahid Ali.

Hybridity became one of the vital issues emerging due to diaspora. Diaspora culture gives birth to the cultural, linguistic, national, ethnic and racial hybridity. Homi Bhabha in The Location of Culture explained the hybridity as “... the historical movement of hybridity as camouflage, as a contesting antagonistic agency functioning in the time lag of sign/symbol, which is a space in- between the rules of engagement" (193). It explains the changing nature of hybridity and its adjustment to the surrounding atmosphere of culture, nation, and state. It shows a positive significance of hybridity. Hybridity shows intercultural or multicultural newborn identity. It also has some negative aspects of mixed identity. John Hutnyk gives the definition of hybridity in his essay Hybridity as:

In its most recent descriptive and realist usage, hybridity appears as a convenient category at 'the edge' or contact point of diaspora, describing cultural mixture where the diasporized meets the host in the scene of migration. (Knott and Mcloughlin eds. 59) 
Heterogeneous condition of diaspora occurred due to maintaining and sustaining the culture of homeland and host land. It also includes language, religion and education. It gives rise to different mixed types of cultural, educational, lingual hybridity and fractured identity in immigrants. Time plays an important role in the developing heterogeneous condition. Heterogeneous conditions are directly in proportion to the time of immigrants stay in a foreign land. Jayaram stated heterogeneous condition of diaspora in his paper entitled The Indian Diaspora in Canada: An Analytical Introduction to Themes and Issues as:

The historically continuous nature of the Indian diaspora [in Canada] and the differences in the educational, economic, regional and linguistic, and religious, sectarian and caste backgrounds of these immigrants -that is, differences carried, and often sustained, by the immigrants from India-and the sustained or created in their new country of residence, necessarily makes the diaspora a heterogeneous one. To this if we add duration of immigrants stay in Canada and the generational differences that naturally set in, this heterogeneous phenomenon becomes even more complex" (Varma and Seshan ed. 27).

Hyphenated identity is somewhat problematic identity as it has two states together whether about culture, nation, race, or language etc. Hyphen shows only a linkage, but it doesn't show degree of attraction, faith, importance between the two. It leads to an imbalance between the hyphenated identities. Pull and push phenomenon can occur in these types of identity. Pull from one side and push from other or pull/push from both the sides. Mind plays a unique role in maintaining this identity. Sometimes it leads to the traumatic, tense condition in the life of a person who carries hyphenated identity. Many issues have been raised due to the phenomenon hybridity. Hyphenated identity is one of them. Diaspora gives birth to this type of national hyphenated identity in the world. It might be called as international hyphenated identity. It represents homeland, continent, and a foreign land linked with each 
other with the hyphen. Radhakrishnan explained his views on hyphenated identity by giving the example of Asian- American as:

When someone speaks as an Asian-American, who is exactly speaking? If we dwell in the hyphen who represents the hyphen; the Asian or American, or can the hyphen speak for itself without creating an imbalance between the Asian and American components...True, both components have status, which has the power and potential to read and interpret the other on its terms? If the Asian is to be Americanized, will the American submit to Asianization? (211) Hybridity thus leads to the problems in the life of migrants. It severely affects the second generation of migrants. The issues of marriage, maintaining culture, identity will be the result of hybrid identity. Society did not accept these types of mixed population. Children suffer a lot because of the mixed identity. They have to face society, school, surroundings, and many places they visit where identity crisis became crucial.

Thus, hybridity is taken into consideration with the race, language, culture, religion, national identities. It has vast area of circumference and encompasses the globe. Diaspora became one of the reasons for hybridity as major issue.

Overall, one can say that diasporic reality is altogether different from the expatriate's imagination. This confrontation with new reality brings cultural shock and manifestation of being alien in the new context. It also brings out the sense of uprootedness. Diasporic reality and problems of identity crisis brings various changes into the mental and behavioral patterns of diasporic community. These changes and adaptation of new patterns brings sense of being hybrid or being in-between. This being in-between-ness can be celebrated positively if community wants to survive and grow in the host land. It leads to formation of new identities, which may wipe out old ones or overlap them. But this adaptation and assimilation with new diasporic realities bring synergy into the lives of diasporic community. 
Types of Hybridity

There are different types of hybridization phenomenon occurring in the world. Hybridity is divided into different types based on culture, language, race, genetics, psychology, and philosophy, etc. These are described as follows:

Linguistic hybridity

Language is an important part of life. It is a medium to express our thoughts, emotions, and feelings. World is a representation of multilingual human gathering. People come together in the process of globalization. They exchange their thoughts, ideas, and language. It resulted into the hybrid language and the phenomenon is known as Linguistic hybridity. For example, in India Indians use many English words in their local language. Racial Hybridity

World is a habitat of different races. People have their own prejudicial thinking against other races. Marriage is the main cause of racial hybridity. Different races come close to each other by the process of marriage.

Cultural hybridity

World is the representation of multicultural gathering. Every culture has its own values, principles, and heritage. It makes their uniqueness, and identity in the world. Different cultures come in a contact with sharing their thoughts. While prejudicial people differentiate culture into dominant and recessive. A marriage is a process by which two cultures are brought together. It shows cultural hybridity.

Biological hybridity 
Children are the genetic print of their parents. They are representations of biological hybridity. Parents may be from different nations, and society. Psychological or Philosophical hybridity

Human psyche is the mystery in the world of human studies. Human psychology is under the influence of contagious spreading of thoughts. Human thought or idea's exchanges lead to psychological hybridity. It is the process of expression of ideas, and thought processing in mind, while the final is the acceptance of thoughts lead to hybridity of desired philosophical thoughts in human mind. Thoughts are transferred from one generation to other. It is a heredity of human thought exchange from old to new generations.

Hybridity in Agha Shahid Ali's Poetic Expression

Agha Shahid Ali is a Kashmiri-American poet. He expresses his diasporic, hyphenated, and hybrid identity.

The poem 'Cracked Portraits' depicts the generations of Ali's family. Portraits, pictures, photographs, images have kept the memories of past alive. It shows the culture, profession, attitude, and philosophy of Ali's family in contemporary period. Those portraits also carried information from the past to present. It also expresses the transfer of characters and the difference between their personalities. Ali mainly focused on his rich cultural, philosophical, and social heritage and its transfer from generation to generation. References of Socrates, Plato, Lenin, and Gandhi focused on the ideology and philosophy through which his family has undergone.

Heredity of philosophy and variation in the ancestral characters gave rise to potential genetic characteristic of the poet. Ali's grandfather was addicted to philosophical ideas of great philosophers like Plato, Socrates. They drank philosophy with the drink. Ali beautifully presents this idea by picturizing addiction, philosophy, and drink together in his poetry as: 
My father went to bring him home.

As he grew older, he moved toward Plato,

mumbling "philosopher-king," (9)

In his cup,

Socrates swirled. (10)

Agha Shahid Ali expressed his grandfather's philosophical life in his poetry. How Philosopher's thoughts attract and penetrate another human mind? is presented by Ali. Later his grandfather gets attracted to Plato's philosophy. It shows mixing and recasting of thought process in human mind. However, Ali's grandfather becomes the mouthpiece of Napoleon in his next phase of life. Socrates also influenced Ali's grandfather. He expressed Socrates' thoughts time to time during breakfast and tea. Philosophical hybridity expresses how one's ideas take charge over human mind and come out through lips in the form of words.

Ali in a poem Cracked Portraits wrote about his family description. He started introducing his family from a strange physician, who cured people with thoughts, and philosophy of Koran. Ali mentioned about his great grandfather, Sahib, and contemporary period of indentured labors. It also highlights the musical period of Malika Pukhraj and Sahib's furious nature.

Ali used the technique of dramatic monologue while describing his father. He expressed the character sporty brilliance of his father who thought in lines of Lenin and Gandhi.

In The Season of the Plains, Ali wrote about Kashmir and the nostalgist memories of his mother. Ali's mother was from Lucknow and she was sharing her childhood memories with Ali as:

In Kashmir, where the year has four, clear seasons, my mother 
spoke of her childhood

in the plains of lucknow, and

of that season in itself, (17)

Ali's mother narrated him the stories of Lord Krishna and the divine music of his flute on the shores of Jamuna. Lucknow and relation of music is also depicted in this poem. For her Lucknow is a sacred place:

the monsoon, when Krishna's

flute is heard on the shores

of the Jamuna (17).

Ali's journey from his birth in Delhi and childhood in Kashmir was mentioned in The Half-Inch Himalayas as given in the above poetic lines. Agha Shahid Ali's father belongs to Muslim community while his mother has Hindu cultural heritage as mentioned above. Therefore, Agha Shahid Ali is a combination of Hindu-Muslim cultural heritage. It reflected in his poetry. It is an example of cultural hybridity. Ali's poetry is a literary feast and example of hybridity in different forms as explained above.

Agha Shahid Ali is a Kashmiri-American poet. His hyphenated identity is an example of hybridity. His poem also expresses the hyphen that create a connection or link between two nations. A migrant's experience in a foreign land is a link between his remembering of motherland and its comparison with a foreign land. Here, Calcutta is acting as a link to connect America and India.

But even

when I pass — in Ohio - the one exit

to Calcutta, I don't know I've begun

mapping America, the city limits

of Evanescence now everywhere. (39) 
Hybridity experience in the life of migrants give birth to the hope and happiness. Migrant start to feel safe and connected with the surrounding environment. It is a very good significance of a positive effect of hybridity.

Agha Shahid Ali uses an imaginary mindscape in his poems. Reader can find it very innovative and attracts to it. Ali compares the rainbow with the positive effect of hybridity. The successful hybridization can bring many colors in the life of migrant. But it comes under the theory of probability.

\section{... I caught a rainbow, its colors slippery in my hands. (85)}

Ali also gives another view about hybridization in his poem. He explains that it is very hard to maintain a relationship in the situation of hybridization as it depends on both natives and migrants. He compared colors with the human relations. Maintaining relations in hybridization is a very challenging aspect in the society. Hands represent connectivity between natives and migrants. Hybridization must be a two-way process between natives and migrants. If there will be a dominant and recessive nature in a relationship then it will lose its viability.

A world is a representation of different cultures, and religions. Every religion has its own faith and regulations. People around the world follow some religion in which they born and brought up. Ali believes in equality. He gives respect to every culture and religion. He writes about the cultural hybridity in his ghazal by giving the examples of some rituals. He writes about the offerings of flowers for prayers in temple as well as mosque.

At the temple and the mosque the rose petals

lay all night perfuming the stunned water. (55)

Offering of flowers as a ritual at the temple and the mosque is an example of cultural hybridity. In both Hindu and Muslim culture flower plays an important role in the prayers. It 
shows that there may be some common origin of every religion. Every religion has the same teaching about unity, peace, and harmony. Religion preaches that humanity should be the only religion in the world.

God expresses different forms and names of God. The word God acts as Refrain or Radif in this ghazal. Prayers in different religions are portrayed with their different meanings. However, faith and belief in God remains the same in all the religions. Concept of secularism bestows equal status to all religions. From beginning to end, journey to God gives an amazing experience to the reader of the ghazal:

Of all things He's the King Allah King God.

Then why this fear of idolizing God? (75)

Here, poet talks of different perception of God in Hinduism and Islam. The beginning couplet shows Hindu and Muslim culture together for their unity in Kashmir. Islam does not believe in idol worshipping. Ali beautifully asked a question in second line of couplet to oppose communal riot, massacre happened in Kashmir. It also remembers exodus of Kshmiri pandit and destruction of God's idols. Poet questions if God is supreme power, then why to object it or make it taboo to idolize God. It is an effort to bridge the gap between both the religions.

\section{Conclusion}

Agha Shahid Ali always wish for a peaceful world. He condemns a terrorist attack happened all over the world. He is optimistic about unity in diversity. He portrays hybridity as a hope in his poetry. Hybridity must connect the different cultures and religion. It should act as a solution for a migrant. Everyone should live a peaceful life. Everyone must accept the similarity and differences present between different cultures. Respect for every religion must be the principal act in the world. 


\section{References}

Ali, Agha Shahid. A Nostalgist's Map of America. W.W. Norton and company, 1991.

Ali, Agha Shahid. Call Me Ishmael Tonight. W.W. Norton and company, 2003.

Ali, Agha Shahid. The Half-Inch Himalayas. Wesleyan University Press, 1987.

Bhabha, H. The Location of Culture. Routledge, 1998.

Hutnyk, John. 'Hybridity'. Diasporas: concepts, intersections, identities, edited by Kim Knott and Sean Mc Loughlin, Rawat Publications, 2011.

Jayram, N. 'The Indian Diaspora in Canada: An analytical Introduction to Themes and Issues', Fractured Identity, edited by Sushma J. Varma and Radhika Seshan, Rawat Publications, 2003.

Knott, Kim., Sean McLoughlin. Diasporas: concepts, intersections, identities. Rawat Publications, 2011.

Radhakrishnan, R. 'Diasporic Meditations: Between Home and Location'. University of Minnesota. 1996. 